\title{
KARAKTERISTIK PRAMUWISATA DALAM PENGEMBANGAN DESA WISATA AGRO DI KABUPATEN BANDUNG BARAT
}

\section{CHARACTERISTICS OF GUIDE IN LOCAL AGRO TOURISM OF BANDUNG BARAT DISTRICT}

\author{
Encang Saepudin ${ }^{1}$, Agung Budiono ${ }^{2,}$ Agus Rusmana ${ }^{3}$ \\ ${ }^{1}$ Prodi IImu Perpustakaan, Universitas Padjdjaran \\ Bandung, Indonesia \\ ${ }^{2}$ Prodi IImu Perpustakaan, Universitas Padjdjaran \\ Bandung, Indonesia \\ ${ }^{3}$ Prodi IImu Perpustakaan, Universitas Padjdjaran \\ Bandung, Indonesia \\ e-mail: encang@unpad.ac.id
}

\begin{abstract}
Abstrak
Berdasarkan pada data RPJMD Kab. Bandung Barat Tahun 2013-2018, Bandung Barat memiliki potensi wisata alam yang sangat besar. Oleh karena itu, pemerintah menetapkan beberapa desa menjadi desa wisata. Selain potensi daerah di sektor agro baik pertanian, perkebunan, kehutanan, peternakan dan perikanan, Kabupaten Bandung Barat juga memiliki beberapa potensi di bidang pariwisata baik wisata alam, wisata minat khusus maupun jenis wisata lainnya. Kawasan wisata KBB dibagi dalam 3 zona wisata utama, yaitu Zona Bandung Utara, Bandung Selatan, dan Bandung Barat. Pada tahun 2014 Pemerintah Kabupaten Bandung Barat menetapkan lima desa menjadi desa wisata. Kelima desa wisata tersebut adalah Suntenjaya di Kecamatan Lembang, Rende (Cikalongwetan), Sirnajaya (Gununghalu), Mukapayung (Cililin), dan Cihanjuang Rahayu (Parongpong). Untuk mengembangkan desa wisata ini diperlukan pengelola yang handal dan berkarakter. Penelitian ini bertujuan untuk mengetahui karakteristik pramuwisata dari segi kredibilitas sumber dan daya tarik sumber. Penelitian ini menggunakan pendekatan kualitatif. Teknik pengumpulan data melalui observasi, wawancara, Focus Group Discussion, dan setudi pustaka. Teknis analisis data yang digunakan adalah analisis data deskriptif dengan langkah reduksi data, penyajian data dan penarikan kesimpulan atau verifikasi data. Uji Validitas dan reliabilitas yang dilakukan yakni melalui proses trianggulasi data dan trianggulasi sumber. Informan dalam penelitia ini adalah para pengelola desa wisata dan Aparatur pemerintahan desa Mekarwangi berjumlah 9 orang. Manfaat penelitian yakni sebagai masukan bagi pemerintah dan beberapa pihak yang terkait mengenai strategi komunikasi (pola komunikasi efektif) dalam pengembangan desa wisata. Hasil penelitian menunjukkan Kredibilitas sumber didasarkan kepada kualifikasi pendidikan atau pengalaman sumber, penguasaan materi wisata agro, dan sikap berbahasa. Sedangkan daya tarik dititikberatkan kepada pembentukan citra diri positif dengan memperhatikan empat komponen yakni sikap, motivasi, persepsi, dan kognisi.
\end{abstract}

Kata Kunci: Desa wisata,Strategi komuniasi, desa wisata agro 


\begin{abstract}
Based on 2013-2018 Bandung District's RPJMD data, Bandung Barat has great natural tourism potential. Therefore, the local government determined some villages to become natural tourism sites. Beside local potential of agro sectors, such as, agriculture, plantation, forestry, animal farms, and fishery, Bandung Barat has also some tourism potentials, both natural tourism, special interest tourism, and other kind of tourism. Bandung Barat District (KBB) tourism areas are divided into three main tourism zones, those are, Bandung Utara (North) Zone, Bandung Selatan (South) Zone and Bandung Barat (West) Zone. In 2014 the government of Bandung Barat District determined five villages as the tourism sites. They are Suntenjaya at Lembang County, Rende (Cikalongwetan), Sirnajaya (Gununghalu), Mukapayung (Cililin), and CihanjuangRahayu (Parongpong). To develop the villages as tourism sites, it is needed reliable and characteristic managers. This research aims to find out guide's character from the source's credibility and attractiveness. This research used qualitative approach. Data was collected through observation, interviews, focus group discussion, and literature study. Data analyzing technique used was descriptive analyses with data reduction, data presentation and conclusion draw or data verification. Validity and reliability test conducted by data and resources triangulation.Informants of this research were tourism village managers and nine local government officers of Mekarwangi. The research's benefits are as input for the government and related parties to communication strategy (effective communication pattern) in tourism village development. The results show that the resources credibility is based on resources's qualification of education or experience, knowledge of agro tourism materials, and language behaviour. Mean while, attractiveness is focused at positive self image form by considering of four components, i.e. attitudes, motivation, perception and cognition.
\end{abstract}

Keywords: Village tourism, communication strategy, agro-tourism

\section{PENDAHULUAN}

Peluang sektor pariwisata cukup prospektif, karena selain sebagai salah satu penghasil pertumbuhan ekonomi, sektor ini diharapkan dapat menjadi pendorong pertumbuhan sektor pembangunan lainnya, seperti sektor perkebunan, pertanian, perdagangan, perindustrian dan lain-lain. Salah satu unsur dari sektor pertanian yang saat ini belum tergarap secara optimal adalah agro wisata (agro tourism). Potensi agro wisata tersebut ditujukan dari keindahan alam pertanian dan produksi di sektor pertanian yang cukup berkembang. (Gumelar S. 2010).

\begin{tabular}{llr} 
Agro & wisata & \multicolumn{2}{c}{ merupakan } \\
rangkaian kegiatan wisata yang \\
memanfaatkan potensi alam dan
\end{tabular} pertanian sebagai obyeknya. Dalam hal ini yang ditonjolkan dalam objek wisata ini adalah Pemandangan alam kawasan pertaniannya maupun kekhasan dan keanekaragaman aktivitas produksi dan teknologi pertanian serta budaya masyarakat petaninya. (Gumelar S.
2010). Kegiatan agro wisata bertujuan untuk memperluas wawasan, pengalaman rekreasi, dan hubungan usaha di bidang pertanian yang meliputi tanaman pangan, holtikultura, perkebunan, perikanan, dan peternakan. Disamping itu, yang termasuk dalam agro wisata adalah perhutanan dan sumber daya pertanian.

Perpaduan antara keindahan alam, kehidupan masyarakat pedesaan, dan potensi pertanian, bila ditata secara baik dan ditangani secara serius dapat mengembangkan daya tarik wisata bagi satu daerah tujuan wisata. Selain itu, dengan berkembangnya agro wisata di satu daerah tujuan wisata akan memberikan manfaat untuk peningkatan pendapatan masyarakat dan pemerintah. Dengan kata lain bahwa fungsi pariwisata dapat dilakukan dengan fungsi budi daya pertanian, pemukiman pedesaan, dan fungsi konservasi.

$$
\text { Upaya pengembangan agro }
$$
wisata pedesaan yang memanfaatkan potensi alam dan pertanian dapat berfungsi sebagai pemberdayaan masyarakat selaras dengan Jurnal IImu Sosial dan Humaniora | 52 
pemberdayaan masyarakat berbasis pariwisata (community based tourism). Pemberdayaan masyarakat dimaksud adalah agro wisata yang dapat mengikutsertakan peran dan partisipasi masyarakat pedesaan. Hal ini selaras dengan pendayagunaan potensi sumber daya alam dan sumber daya manusia yang dimilikinya. Persoalannya adalah bagaimana masyarakat pedesaan bisa dibina secara berkesinambungan, agar potensi-potensi yang dimiliki daerah digali secara optimal, sehingga dapat memberikan hasil maksimal bagi petani, masyarakat desa, pengusaha dan menjadi sumber pendapatan yang dapat diandalkan.

Berdasarkan kepada hasil pengamatan di lapangan, pada saat ini antara pelaku pariwisata dan pelaku pertanian masih berjalan sendiri-sendiri. Dalam hal ini belum ada komunikasi dan koordinasi diantara pihak-pihak yang berkepentingan untuk pengembangan desa wisata. Hal ini terjadi karena belum terbentuknya lembaga secara formal sebagai pembina masyarakat dalam pengmbangan desa wisata. Sehingga keberadaan lembaga formal sebagai pembina diperlukan keberadaannya. Oleh karena itu, perlu adanya pola pembinaan agro wisata agar para pelaku pariwisata dan pelaku pertanian secara sinergis dapat merencanakan, menyusun, memprogramkan agro wisata yang bermanfaat bagi masyarakat, pengusaha dan pemerintah. Dalam hal ini perlu adanya komunikasi yang baik antarpihak yang berkepentingan. Dengan terjalinnya komunikasi yang baik antarpihak maka harmonisasi sosial dalam pengembangan desa wisata agro ini akan tercapai. Dalam hal ini kemampuan berkomunikasi dan penggunaan strategi komunikasi harus dimiliki oleh semua pihak.

Effendy dalam buku IImu Komunikasi Teori dan Praktek menyatakan ada empat tujuan dalam strategi komunikasi sebagai berikut (1) To Secure Understanding yaitu untuk memastikan bahwa terjadi suatu pengertian dalam berkomunikasi.(2) To Establish Acceptance, yaitu bagaimana cara penerimaan itu terus dibina dengan baik. (3) To Motivate Action yaitu penggiatan untuk memotivasinya, dan (4) To Goals Which Communicator Sought To Achieve yaitu bagaimana mencapai tujuan yang hendak dicapai oleh pihak komunikator dari proses komunikasi tersebut. (Effendy, 2000:32).

Berdasarkan hal tersebut, hal pokok yang harus diperhatikan ketika menyusun strategi komunikasi adalah dengan merperhatikan segala kelebihan dan kekurangan yang melekat pada komponen-komponen komunikasi terutama yang terkait dengan pesan, komunikaror, dan media.

Berdasarkan pada data RPJMD

Kab.Bandung Barat Tahun 2013-2018, Kabupaten Bandung Barat memiliki potensi wisata alam yang tidak sedikit.

Berdasarkan pada data RPJMD Kab. Bandung Barat Tahun 2013-2018, Bandung Barat memiliki potensi wisata alam yang sangat besar. Oleh karena itu, pemerintah menetapkan beberapa desa menjadi desa wisata. Selain potensi daerah di sektor agro baik pertanian, perkebunan, kehutanan, peternakan dan perikanan, Kabupaten Bandung Barat juga memiliki beberapa potensi di bidang pariwisata baik wisata alam, wisata minat khusus maupun jenis wisata lainnya. Kawasan wisata KBB dibagi dalam 3 zona wisata utama, yaitu Zona Bandung Utara, Bandung Selatan, dan Bandung Barat. Misalnya, di Kecamatan Padalarang terdapat Situ Ciburuy yang terkenal sejak dahulu karena danau ini terletak dipinggir jalan raya Bandung - Jakarta tempatnya ada di Pusat Kota Padalarang. Kemudian di Kecamatan Cipatat terdapat Gua Pawon. Gua Pawon merupakan situs manusia purba yang ada di dunia termasuk Karst Kelas I. Gua ini merupakan aset nasioanl bahkan aset dunia. Pada saat ini disekitar lokasi Gua Pawon sedang dibangun Kampung Wisata secara bertahap. Selain itu juga di Kecamatan Cipatat terdapat Air Panas Cisameng, Gua Sanghiang Tikoro, Curug Jawa dan Waduk Sguling, kemudian Waduk Cirata di Kecamatan Cipeundeuy yang merupakan Pembankit Listrik Tenaga Air (PLTA) terbesar di Asia Tenggara. Sedangkan di Cikalong Wetan terdapat Wisata Agro Perkebunan 
Selain itu, Sebelah utara Kabupaten Bandung Barat kaya akan potensi alam dengan kondisi tanah dan suhu udara tertentu menjadikan lahan pertanian yang subur. Desa Cihideung Kecamatan Parongpong terdapat Area Agrowisata yang ditumbuhi berbagai jenis bunga dengan koleksi berbagai spesies anggrek dan bunga-bunga lainnya dengan berbagai bentuk dan warna menarik. Di desa Cihideung ini lebih dari $80 \%$ warga desa Cihideung menjadi petani bunga, dimana terdiri dari $30 \%$ petani bunga potong, dan $50 \%$ petani bunga hias.

Kawasan ini memang tepat disebut sebagai kawasan wisata bunga, karena di sepanjang desa ini terlihat berbagai tanaman bunga yang dikembangbiakkan. Berbagai jenis tanaman bunga bisa kita temui di desa Cihideung ini, dari tanaman hias hingga tanaman potong. Tanaman (bunga) hias biasanya adalah tanaman yang digunakan untuk memperindah taman, dan tanaman (bunga) potong biasanya adalah tanaman/ bunga yang diperlukan untuk keperluan dekorasi.

Berdasarkan uraian diatas maka masalah yang diangkat akan dirumuskan dalam bentuk pertanyaan penelitian yaitu "Bagaimana Stratgi pemilihan komunikator dalam pengembangan desa wisata agro di Kabupaten Bandung Barat,".

\section{TUJUAN PENELITIAN}

Berdasarkan kepada rumusan masalah, maka tujuan penelitian ini adalah mengetahui strategi pemilihan komunikator terutama dari segi kredibitas sumber dan daya tarik sumber dalam pengembangan desa wisata agro di Kabupaten Bandung Barat.

\section{METODE}

Penelitian ini menggunakan pendekatan kualitatif. ${ }^{1}$ Pendekatan ini

\footnotetext{
Travers, Max (2001).Qualitative Research Through Case Studies, London: Sage Publications, hal. 9-10. Bandingkan dengan dengan konsepsi Neuman, Lawrence W (1994), Social Research Methods Qualitative and Quantitative Approachs. Boston:Allyn and Bacon, hal. 62
}

dipilih agar studi ini memperolah gambaran detail dan mendalam informasi mengenai suatu gejala sosial tertentu yang bersifat fenomenologis. Berdasarkan tujuannya, penelitian ini termasuk dalam kategori penelitian deskriptif, yaitu penelitian yang berusaha menggambarkan rincian-rincian spesifik dari situasi, setting atau relasi-relasi sosial yang berlangsung dalam lingkup subyek penelitian. Informan dalam penelitia ini adalah para pengelola desa wisata dan Aparatur pemerintahan desa Mekarwangi berjumlah 9 orang. Teknik pengumpulan data yakni observasi, wawancara, Focus Group Discussion, dan suti pustaka. Teknis analisis data yang digunakan adalah analisis data deskriptif, secara umum berupa reduksi data, penyajian data dan penarikan kesimpulan atau verifikasi data. Uji Validitas dan reliabilitas yang dilakukan yakni melalui proses trianggulasi data dan trianggulasi sumber.

\section{HASIL DAN PEMBAHASAN}

Pramuwista merupakan hal yang penting dalam proses penyebaran informasi, penerimaan informasi yang baik dapat diterima oleh komunikan bergantung pada baik atau buruknya komunikator dalam menyampaikan pesan dan menggunakan media. Komunikator dalam penyebaran informasi di Desa Wisata Agro merupakan sumber informasi bagi pengunjung di Desa Wisata Agro. Oleh karena itu, kemauan belajar yang tinggi dan kemampuan organisasi yang baik menjadi nilai penting dalam pemilihan komunikator atau pengelola wisata di desa wisata agro. Hal ini dikemukakan oleh aparat desa yakni lbu Siti, Kasie Pelayanan. la menyatakan;

"Yang utama adalah kemauan yang tinggi, harus pintar organisasi juga. Kemauan yang tinggi, karena belajar bisa menyusul, latar belakang juga dicek, Cuma bukan sebagai penentu"

"kedah nu mampuh nu palalinter" (note : semua perangkat desa Mekarwangi berlatar belakang pendidikan paling tinggi D.3 sedang yang lain SMA/SMP). Alasan kesibukan pelayanan masyarakat serta wilayah pedesaan yang medannya cukup 
berat menjadikan hal tersebut belum direalialisasikan.

(Siti, Kasie Pelayanan : 2016)

Latar belakang pendidikan merupakan hal yang penting dalam pemilihan pengelola wisata di desa wisata agro, namun bukan menjadi hal penentu dalam proses pemilihan. Dengan berbekal pengalaman dan belajar dari berbagai media bisa menjadi dasar dalam menentuan orang yang akan ditunjuk untuk mengelola desa wisata. Pada dasarnya pengelola wisata memiliki kewajiban untuk dapat menyampaikan informasi mengenai berbagai informasi yang dimiliki oleh desa wisata. Oleh karena itu, pengelola desa wisata sangat jeli dalam memilih komunikator. Strategi dalam pemilihan komunikator yang dituntut untuk memiliki kriteria dan standar-standar tertentu. Adapun kriteria dan standar tersebut yakni kredibilitas sumber dan daya tarik sumber.

\section{a. Kredibilitas Sumber}

Sesuai dengan hasil observasi peneliti di lapangan, kredibilitas atau kemampuan yang dimiliki oleh pengelola wisata Desa Wisata Agro dapat diukur dengan penguasaan bahasa yang dimiliki oleh seorang pengelola wisata dalam menyampaikan informasi kepada masyarakat. Penguasaan bahasa yang baik akan membuat pengunjung atau komunikan dapat menerima informasi atau pesan dengan baik, mengingat banyaknya informasi dengan istilah-istilah khusus di wisata agro dan informasi tersebut harus disampaikan kepada pengunjung yang berbeda-beda. Selain menguasai bahasa, dalam menyampaikan pesan atau informasi yang ada, pengelola wisata harus dapat menyampaikannya dengan baik, baik dengan artikulasi suara yang benar atau gestur tubuh yang tepat.
"Yang utama adalah kemampuan bahasa. kita harus bisa "ngobrol", kemudian bahasa itu harus bisa disampaikan dengan jelas ke orang yang awam, di desa ini kan ada istilahistilah khusus, terutama istilah dalam pertanian, peternakan dll. Bagaimana kita menyampaikan ke pengunjung agar mereka mengerti istilah yang tadi, katakatanya kita buat umum. Selain itu, harus menyampaikannya jelas gak usah panjang lebar, yang penting mereka paham, dan juga dengan bahasa yang baik dan juga sopan." (Ibu Siti, Kasie Pelayanan 2016 )

Hal tersebut sejalan dengan pendapat dari Berlo, 1962 dalam Cangara, 2013 menyebutkan bahwa ".. kredibilitas seorang komunikator bisa timbul jika ia memiliki keterampilan berkomunikasi (Communications Skills), pengetahuan yang luas tentang materi yang dibawakan (knowledge) sikap jujur dan bersahabat (attitude) serta mampu beradaptasi dengan sistem sosial, budaya (social and cultural system) masyarakat yang dihadapinya".

Oleh karena itu, sangat penting bagi seorang pengelola wisata sebagai penyebar informasi kepada masyarakat untuk dapat berkomunikasi dengan tepat, yang mampu mengolah pesan dengan cermat sehingga informasi dapat sampai ke semua lapisan masyarakat, terutama masyarakat pengunjung. Hal yang paling penting adalah mengetahui secara mendalam mengenai informasi yang akan di sampaikan kepada msyarakat.

Sikap sopan, jujur, dan bersahabat merupakan sikap yang dapat membuat pengunjung lebih mudah menerima pesan yang disampaikan, sehingga proses komunikasi berjalan efektif. Kemampuan beradaptasi 
dengan sistem sosial dan budaya juga perlu diperhatikan, mengingat pengunjung yang ditemui sangat beragam dan berasal dari berbagai daerah. Mereka memiliki keragaman sikap, perilaku, gaya, bahasa, dan nilai. Dengan keragaman itu, pengelola desa wisata dituntut untuk mampu menyesuaikan diri dengan kondisi tersebut.

\section{b. Daya Tarik Sumber}

Selain kredibilitas, daya tarik (attractiveness) merupakan hal yang sangat penting. Hal ini berpengaruh dalam penyebaran informasi oleh pengelola wisata kepada masyarakat. Daya tarik akan berhubungan dengan kredibilitas yang dimiliki oleh seorang pengelola wisata dalam menyampaikan pesan. Salah satu contoh berbicara dengan sopan, murah senyum, berpakaian yang rapi dan bersih, dan lainnya.

Pengelola wisata sebagai bagian dari pelayanan publik harus mampu menarik perhatian pengunjung dengan daya tarik yang dimiliki. Pengelola Desa Wisata Agro harus menunjukkan daya tarik yang bagus sehingga dapat menarik perhatian pengunjung. Misal. Berpakaian nyunda, berbahasa santun, jelas, dan sistematis. Pakaian yang dikenakan akan menujuukan kehasan bagi daerah wisata. Dengan berpakaian seperti ini akan menjadi jati diri bagi para pengelola. Selain itu, penggunaan bahasa yang santun, suara yang jelas, dan yang diatur sedemikian rupa merupakan salah satu cara agar perhatian pengunjung tidak teralihkan perhatiannya ketika pengelola wisata menyampaikan pesan. Cara penyampaian informasi yang tidak monoton dan disesuaikan dengan pengunjung yang dihadapi, good looking atau berpenampilan menarik merupakan faktor daya tarik yang harus diperhitungkan oleh seorang pengelola wisata. Penampilan yang nyaman untuk dilihat seperti bersih,rapi, akan menimbulkan citra tertentu kepada pengunjung sehingga dapat menumbuhkan rasa percaya akan keprofesionalan seorang pengelola wisata. Hal ini tergambar dari data hasil wawancara dengan informan. la menyatakan bahwa: "serang pengelola wisata itu kan harus berpenampilan rapi dan menarik. gak perlu cantik atau gimana yang penting bersih, rapi. Selain itu, yang terpenting adalah cara menjelaskan kepada pengunjung harus disesuaikan level pengunjungnya, apakah itu anakanak, dewasa, atau orang tua itu kan berbeda-beda, kadang kalau cara kita enak mereka akan perhatian" (Ibu Siti, Kasie Pelayanan 2016).

Cirta diri yang positif harus terus dibangun oleh seluruh pengelola desa wisata. Citra diri tebentuk dari persepsi seseorang tentang diri sumber, baik secara internal maupun eksternal persepsi ini mencakup perasaan dan sikap yang ditunjukkan pada diri. Citra diri dipengaruhi oleh pandangan pribadi tentang karakteristik dan kemampuan fisik dan oleh persepsi dari pandangan orang lain. Sikap, nilai cultural, dan sosial juga mempengaruhi pada perkembangn citra diri. (Perry \& Potter, 2005 ).

Proses pembentukan citra atau kesan terhadap suatu obyek, diri seseorang, melibatkan empat komponen penting dalam diri individu. Empat komponen tersebut adalah sikap, motivasi persepsi, dan kognisi. Walter Lipman, seorang pakar psikologi sosial, menyebut empat rangkaian itu, dengan nama, picture in our head. (1) sikap, adalah kecendrungan bertindak, berpersepsi, berpikir guna 
menghadapi obyek, ide, situasi atau nilai. Sikap bukan perilaku, tetapi merupakan kecendrungan untuk berperilaku dengan cara tertentu. Sikap menentukan apakah seseorang harus pro atau kontra terhadap sesuatu, menentukan apa yang disukai, diharapkan dan diinginkan. Sikap pun mengandung aspek evaluatif artinya mengandung nilai menyenangkan atau tidak menyenangkan. Yang paling penting pula, sikap ini juga dapat diperteguh, atau pun diubah (2) motif adalah keadaan dalam pribadi seseorang yang mendorong keinginannya melakukan kegiatan-kegiatan tertentu guna mencapai suatu tujuan (3) Persepsi diartikan sebagai hasil pengamatan terhadap unsur lingkungan yang dikaitkan dengan suatu proses pemaknaan. Persepsi atau pandangan individu akan positif apabila informasi yang diberikan oleh rangsangan dapat memenuhi kognisi individu. (4) Kognisi yaitu suatu keyakinan diri dari individu terhadap stimulus. Keyakinan akan timbul apabila individu telah mengerti rangsangan tersebut, sehingga individu harus diberikan informasi-informasi yang cukup yang dapat mempengaruhi perkembangan kognisinya.

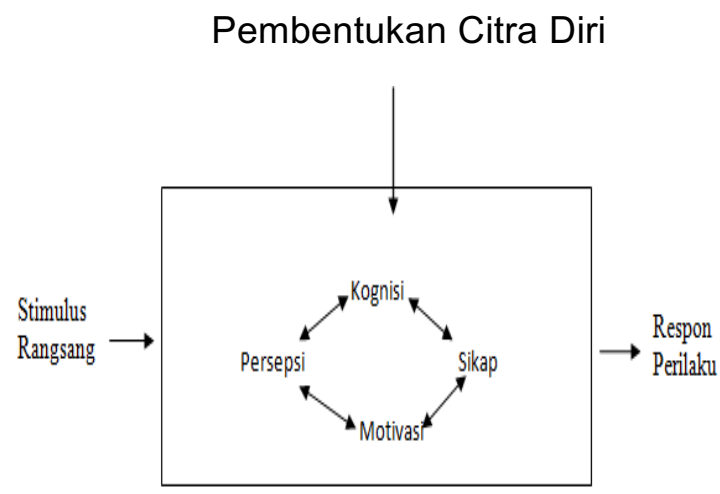

Gambar 1. Pembentukan Citra Diri

Sumber: Soleh Soemirat dan Elvinaro Ardianto. 2010;115
Faktor pendukung dan penghambat dalam menentukan pengelola desa wisata

Pengelolaan desa wisata di Desa Mekarwangi memiliki hambatan yang cukup rumit. Ada beberapa faktor yang menjadi hambatan dalam pengembangan desa wisata di Desa Mekarwangi. Hal yang peling mendasar adalah ketersediaan sumberdaya manusia sebagai motor penggerak dalam mengelola desa wisata. Pada saat ini pengembangan desa lebih bertumpu pada aparat desa. Sedangkan aparat desa sangat terbatas, baik dari segi kuantitas maupun kualitas. Dari segi kualitas aparat desa Mekarwangi paling tinggi berpendidikan D3 bahkan ada yang berpendidikan SMP. Sedangkan untuk tim pengelola desa wisata harus memiliki memampuan khusus secara akademik, paling tidak lulusan D3 Pariwisata. Selain itu, dengan kesibukan yang dimiliki oleh para aparat desa menjadi alasan kuat untuk tidak ikut serta dalam pengembangan desa wisata. Hal ini tergambar dari hasil wawancara dengan ibu siti. la manyatakan.

Namun demikian, semangat untuk terus mengembangkan desa wisata ini sangat kuat. Hal ini terlihat dari semangat para aparat Desa Mekarwangi yang ingin memiliki wilayah wisata yang menjadi kebanggaan masyarakatnya. Selain itu, pemerintah Kabupaten Bandung Barat sangat mendorong/ mendukung untuk pengembang desa wisata. Mengingat wilayan Bandung Barat memiliki potensi yang sangat besar untuk pengembangan desa wisata. Hal ini terungkap di pernyataan yang diungkapkannhya.

Dengan keterbatasan yang dimiliki, selama ini pemerintahan desa belum bisa memaksimalkan program pengembangan desa wisata. Pemerintahan desa baru melakukan program sosialisasi pengembangan desa wisata kepada tokoh-tokoh masyarakat, pemuda, dan perangkat RT/ RW. Program sosialisasi ini dilakukan sebagai awal dari kegiatan pengembangan desa. Menurut tim aparat desa, sosialissi ini mendapat respon yang positif dari masyarakat. Terutama masyarakat yang 
mata pencahariannya dibidang pertanian dan kuliner.

Media yang digunakan untuk proses sosialisasi peogram desa wisata agro ini adalah media formal dan informal. Media formal seperti rapat rutin yang dilakukan setiap bulan. Pertemuan rutin ini dihadiri oleh para tokom masyarakat, tokoh agama, para pemuda, RT dan RW, dan para kader PKK. Selain melalui rapat rutin yang sifatnya formal, proses sosialisasi dilakukan dengan pendekatan personal dan pendekatan keagamaan. Pendekatan persolal terutama dilakukan kepada para tokoh agama. Hal ini dilakukan karena tokoh agama memiliki peran penting dalam kehidupan masyarakat. Sebagian besar tokoh agama ini lebih dipercaya dan diikuti oleh para masyarakat.

Pendekatan keagamaan pada prinsipnya sangat terkait erat dengan pendekatan personal, hanya saja pendekatan keagaaan dilakukan pada saat pelaksanaan pengajian rutin di setiap menjit. Pendekatan keagamaan merupakan tidak lanjut dari pendekatan personal. Hasil pendekatan personal terhadap para tokoh agama langkah berikutnya pendekatan kepada masyarakat melalui tokoh agama tersebut melalui pertemuan-pertemuan rutin keagamaan seperti pengajian rutin dan diskusi keagaamaan.

Ada beberapa potensi desa yang bisa menjadi pendukung terlaksananya program desa wisata agro di desa Mekarwangi terutama untuk menentukan standar para pengelola desa wisata. Di Desa Mekarwangi ini terdapat kompleks perumahan yang sangat strategis dari segi sumberdaya manusia. Kompleks perumahan ini adalah kompleks dosen ITB PPPR Mekarwangi. Keberadaan kompleks ini menggambarkan ketersediaan sumberdaya manusia di desa Mekarwangi untuk menjadi pengelola desa wisata.

Keberadaan kompleks dosen ITB PPPR Mekarwangi, menandai bahwa sebenarnya warga desa Mekarwangi pun meliputi kaum terdidik dengan penguasaan teknologi yang mumpuni. Ketua RW di PPPR Dosen ITB tersebut bergelar Doktor sehingga sebenarnya bisa diberdayakan. Hanya saja para perangkat desa sepakat perlu dilakukan pendekatan kepada kelompok dosen ITB tersebut, sehingga dapat diberdayakan dalam pengembangan desa wisata agro. (Yopie , Staf IT Desa, 2016)

\section{SIMPULAN DAN SARAN}

Karakteristik Pramuwisata Dalam Pengembangan Desa Wisata Agro Di Kabupaten Bandung Barat hal yang sangat penting dalam pengembaangan desa wisata agro terutama berkaitan dengan pembangunan kredibilitas sumber dan daya tarik sumber. Kredibilitas sumber didasarkan kepada kualifikasi pendidikan atau pengalaman sumber, penguasaan materi wisata agro, dan sikap berbahasa. Sedangkan daya tarik dititikberatkan kepada pembentukan citra diri positif dengan memperhatikan empat komponen yakni sikap, motivasi, persepsi, dan kognisi.

\section{UCAPAN TERIMAKASIH}

Dalam kesempatan ini penulis mengucapkan terima kasih kepada semua pihak yang telah mendukung terlaksananya penelitian ini. Secara Khusus penulis mengucapkan terima kasih kepada Dekan Fakultas Komunikasi Unpad, Ketua LPPM Unpad, Ketua Program Studi IImu Perpustakaan Fakultas IImu Komunkasi Unpad, dan Pemerintah kabupaten Bandung Barat terutama

\section{DAFTAR PUSTAKA}

Aprinta E.B, Gita. 2014. Strategi Cyber Public Relations dalam Pembentukan Citra Institusi Pendidikan Tinggi Swasta THE MESSENGER, Volume VI, Nomor 1, Edisi Januari 2014

Arikunto, Suharsimi. 2010. Prosedur Penelitian Suatu Pendekatan Praktik. Jakarta: Rineka Cipta.

Barker, Chris. et. al (2002) Research Methods in Clinical Psychology: An Introduction for Students and Practitioners Wiley \& Sons. London

Despica, Rika. Pemberdayaan Masyarakat Dalam Pengembangan Agro Wisata Kebun Teh Di Kabupaten Solok Provinsi 
Sumatera Barat. Sumatera Barat: Program Studi Pendidikan Geografi STKIP PGRI

Effendy, Onong Uchjana. (2000). IImu Komunikasi Teori dan Praktek. Bandung: PT Remaja Rosdakarya.

Poewanto, Hari. 2000. Kebudayaan dan Lingkungan dalam Perspektif Antropologi.Cetakan I. Yogyakarta : Pustaka Pelajar

Rohidi, Tjetjep Rohendi. 2000. Ekspresi seni orang miskin: Adaptasi simbolik terhadap kemiskinan. Bandung. Nuansa cendikia.

Sugiyono. 2008. Metode penelitian kuantitatif kualitatif dan $R$ \& $D$. Bandung : Alfabeta.

Soemirat, Sholeh dan Elvinaro Ardianto. 2010. Dasar-dasar Public Relations. Bandung; Remaja Rosdakarya

Sugiyono. 2008. Metode Penelitian Bisnis. Bandung. Alfabeta

Sutopo. HB. 2006. Metode Penelitian Kualitatif, Surakarta: UNS Press.

Sastrayuda, Gumelar S. 2010) Hand Out Mata Kuliah Concept Resort And Leisure, Strategi Pengembangan Dan Pengelolaan Resort And Leisure. https://www.google. com/\#q=Agro+ wisata+ merupakan+rangkaian+kegiatan+w isata+yang+memanfaatkan+potens $\mathrm{i}+\&$

Yusup, Pawit M. 2013. Perilaku Pencarian Informasi Penghidupan Pada Penduduk Miskin Pedesaan. Bandung; Universitas Padjadjaran. 